\title{
FIRST LAWS: TIKANGA MĀORI IN/AND THE LAW
}

Jacinta Ruru*

This address is the 10th Shirley Smith Memorial Lecture given in Wellington on 18 October 2017. It considers the possibility for the enhanced role of first laws - the laws of Indigenous peoples - within contemporary settler legal systems.

\section{INTRODUCTION}

Tēnā koutou katoa. Ngā mihi nunui ki te mana whenua o te rohe nei. I ngā mana, i ngā rangatira, i ngā reo, tēnā koutou, tēnā koutou, tēnā koutou.

It is a privilege to be here with you this evening in memory of Shirley Smith, one of Aotearoa New Zealand's truly great early women of the law and, of particular significance for me, New Zealand's first woman law lecturer. ${ }^{1}$ These past months I have had many delightful moments absorbing all I could about Shirley who worked with and represented many Māori clients. She was, in part, inspired into the profession of law through conversations with her father, the late Sir Justice David Smith, whose practice included a specialisation in Māori land law. It is these professional practice connections to Māori in the law that I honour this evening, in gratitude to Shirley and her family who have stood for issues of justice, what is right, and just getting the job done. In particular, I ground this address in the lecture room, within the context of legal education, in acknowledgment of Shirley as our country's first female to teach law.

In doing so, this address considers the role of first laws - the laws of Indigenous peoples - within contemporary settler legal systems. If settler legal systems wish to realise aspirations for legal reconciliation with Indigenous peoples, then an important component of this is to recognise

* Jacinta Ruru FRSNZ (Raukawa, Ngāti Ranginui), Professor of Law, University of Otago; Co-Director, Ngā Pae o te Māramatanga New Zealand's Centre of Māori Research Excellence; and Co-Director, University of Otago Poutama Ara Rau Research Theme. My thanks to Kyla Mullen for her outstanding research assistance.

1 Shirley Smith (1916-2007) was the 41st women to be admitted as a barrister and solicitor in New Zealand and the first female legal academic at a New Zealand university. A website which commemorates Shirley Smith has been created by the Women in Law Committee of the New Zealand Law Society's Wellington branch. The Shirley Smith Address commenced in 2008 and is now a well-established annual event in Wellington. 
Indigenous peoples' laws. New Zealand's Parliament has a long history of grappling with and mostly denying, but sometimes accommodating, Māori law. Historically, Māori law was recognised as existing but undesirable by the colonial establishment of government. Today there is a semblance of recognition of Māori law throughout our state legal system including, significantly, the legal recognition of the environment having Indigenous agency. This address reflects on this journey towards reconciliation and restitution in New Zealand considering specifically the role of Māori within the profession of law and the opportunity for our first laws - tikanga Māori - to be firmly recognised as an important component of our legal education.

\section{CONTEXT FIRST: WOMEN AND MÄORI IN THE LEGAL PROFESSION}

In reading the wonderfully generous work by Shirley, and the work of others about Shirley, I have been reflecting on the place of women and Māori in the law. ${ }^{2}$ It is certainly remarkable that the influence of women in the law reaches back a little over a mere century. While Ethel Benjamin was New Zealand's first female lawyer, who, also, in 1897 became the first female in the British Empire to appear as counsel in the court (representing a client for the recovery of a debt), ${ }^{3}$ Shirley's experience of law school in the 1950s was still one of being on the frontier, pushing the boundaries of the profession. Shirley sat in a law lecture room with only five other women law students. One of Shirley's accounts of Victoria University of Wellington law school in 1951 (more than 50 years after Ethel had graduated) is, in her words: ${ }^{4}$

... in a Legal Ethics lecture, we were warned against chatting about our cases over dinner at home "with the little woman". I rose and asked if this stricture applied equally to "the little man". This brought the house down.

When Shirley graduated with her law degree, she was the first women to do so in many years. It was a time when women were customarily excluded from the Victoria University of Wellington Law Faculty Club's annual dinner. In Shirley's wonderful "My Life in the Law" account, she recollects that after finishing her last exam, she arrived at the annual dinner and: ${ }^{5}$

2 The past nine addresses are available to view on the Shirley Smith Address website <https://shirleysmithaddress.org> and have been delivered by Margaret Wilson, Dame Sian Elias, Professor Nicola Lacey, Sir Kenneth Keith, Professor Hilary Charlesworth, Justice Teresa Doherty, Dame Susan Glazebrook, Dame Silvia Cartwright and Professor Ngaire Naffine.

3 See Janet November In the Footsteps of Ethel Benjamin: New Zealand's Woman Lawyer (Victoria University Press, Wellington, 2009); and Nicola Peart "Property Rights on Death: Policies in Conflict" (2017) 15 Otago LR 25.

4 Shirley Smith "My Life in the Law" (2014) 45 VUWLR 1 at 1.

5 At 2 (emphasis omitted). 
I was the only woman present. It did not bother me in the least. It was so much easier for me than it would have been for any of the [other women]. I was older, married, had studied and lived abroad and had some experience of the life in the world: besides, I had always regarded men as people.

I love this comment because, of course, men did not always regard women as people. ${ }^{6}$ The female trailblazing in law began with Ethel. Shirley and others continued turning the profession on its head to carve out a place for women as lawyers.

Just as Ethel broke the initial ground in the late 1890s for women, Sir Āpirana Ngata did so for Māori. ${ }^{7}$ Ngata completed his LLB in 1896 representing the first formal entry of Māori into the legal profession. But as was the experience with women, this first for Māori did not immediately lead to any sizable numbers of Māori graduating in law. ${ }^{8}$ In the context of women, Shirley broke new ground in the 1950s. In the context of Māori, the momentum of Māori in the law and breaking new ground from within the law did not begin to germinate until the 1970s.

Of significance, the now Sir Eddie Taihakurei Durie was appointed as the first Māori judge to sit on the Māori Land Court in 1974 and later, in 1980, became its Chief Judge and Chairperson of the Waitangi Tribunal. ${ }^{9}$ In 1977, Māori lawyers in Auckland attempted to set up a "Brown Bar" - that was primarily the work of Hemi Rua Ropata, James Rota and Manu Rogers. ${ }^{10}$ Some of our prominent Māori today were beginning to graduate at this time: Louis Bidois, John Chadwick, Denise Clark, Charl Hirschfeld, Moana Jackson, Shane Jones, Prue Kapua, Paul Majurey, Stephanie Milroy, Moana Maniapoto, Annette Sykes, John Tamihere and Joe Williams to name a few.

6 Bettina Bradbury "From Civil Death to Separate Property: Changes in the Legal Rights of Married Women in Nineteenth-Century New Zealand" (1995) 29 New Zealand Journal of History 40; and Margaret Briggs "Historical Analysis" in Nicola Peart, Margaret Briggs and Mark Henaghan (eds) Relationship Property on Death (Thomson Brookers, Wellington, 2004) 1 at [1.2].

7 See Ranginui Walker He Tipua: The Life and Times of Sir Apirana Ngata (Penguin Books, Auckland, 2005); and AH McLintock (ed) "Ngata, Sir Apirana Turupa" in An Encyclopaedia of New Zealand (Government Printer, Wellington, 1966)

8 See generally Mason Durie "Indigenous Higher Education: Māori Experience in New Zealand" (paper presented to the Australian Indigenous Higher Education Advisory Council, Canberra, Australia, 1 November 2005). For a woman's perspective of law school in the 1970s see Anonymous "Law: Sexist Beginnings" (1976) 37 Broadsheet 20.

9 Ministry of Justice "An Index of Past and Present Judicial Officers of the Māori Land Court and Native Land Court" (1 July 2016) Māori Land Court <www.maorilandcourt.govt.nz>; Mark Derby "Waitangi Tribunal: Te Rōpū Whakamana - Developing the Tribunal, 1980s" (20 June 2012) Te Ara - The Encyclopedia of New Zealand <https://teara.govt.nz>; and "New Judge for Māori Land Court" [1974] NZLJ 342. To view some of Durie's work see Waitangi Tribunal Motunui-Waitara Report (Wai 6, 1983); and ET Durie "Will the Settlers Settle? Cultural Conciliation and Law" (1996) 8 Otago LR 449.

10 John Te Manihera Chadwick "The Māori Law Society - How it all Began" (2008) Te Hunga Rōia Māori o Aotearoa <www.maorilawsociety.co.nz> at 1 . 
This stunning photo below, that I love very much, was taken in 1985 at the Auckland High Court, where two Māori women lawyers - Annette Sykes and Sharon Opai - moved Sarah Reeves and Frances Eivers in their admission to the bar (with Reeves and Eivers now both judges). ${ }^{11}$ At this time Māori were beginning to mark out territory within the legal profession: the Māori Law Society was founded in 1988 with John Chadwick as President. ${ }^{12}$

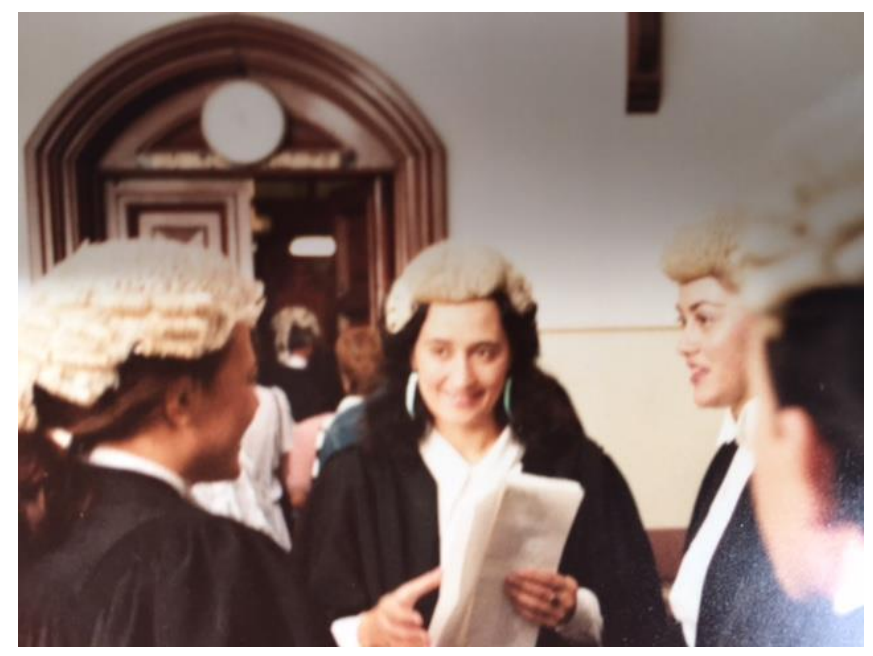

Photo: Auckland High Court, 1985. Source: Judge Sarah Reeves.

Turning to today, while the country might bemoan that there are too many lawyers, this is not true for Māori in the study or practice of law $^{13}$ (and it is not true for women in the highest reaches of our

11 Judge Frances Eivers was appointed as a District Court judge in 2009. Judge Sarah Reeves was appointed as a Māori Land Court judge in 2010.

12 Chadwick, above n 10, at 4. Initial office bearers were John Te Manihera Chadwick (Rotorua), Gary ("Mr Fiscals") Dyall (Wellington), Denise Clark (Rotorua), Rawiri Rangitauira (Rotorua), and Sarah Reeves (Auckland). John Chadwick graduated with his LLB in the 1960s from Victoria University of Wellington and went on to have a distinguished legal career (he passed away in 2017): see Geoff Adlam "John Te Manihera Chadwick MNZM, 1945-2017" (1 June 2017) New Zealand Law Society <www.lawsociety.org.nz〉.

13 While 1,224 students completed law qualifications at New Zealand universities in 2016 (including LLB, LLB Hons, LLM and PhD in Law), 115 identified as Māori (9.4 per cent): Greg Murray, Planning and Funding Office, University of Otago (11 October 2017). Of the 12,822 practising lawyers working in New Zealand on 10 October 2017, 765 identified as Māori (6 per cent): Geoff Adlam "Slightly More Male Lawyers than Female" (24 October 2017) New Zealand Law Society <www.lawsociety.org.nz>. 
legal profession). ${ }^{14}$ Women, and more so Māori, are still finding footholds to grasp in many parts of the legal profession.

In the context of gender, despite female students significantly outnumbering male students in the study of law for some decades now, ${ }^{15}$ we know this has not yet translated, in any overall substantial and sustained manner, into the practice of law and particularly female partnership in law firms. ${ }^{16} \mathrm{In}$ academia, where Shirley began lecturing Roman Law and Constitutional Law in the 1950s, my rudimentary collation of contemporary gender statistics completed this month, October 2017, shows gender parity has not yet been attained. By simply counting staff numbers on the websites of the six law schools, it appears that of a total of 178 law academics, 40 per cent are female (with Canterbury leading the way on the gender equity front with 15 male and 14 female academics and both Dean and Deputy Dean positions being held by women). In recent years, change at the top of academia has commenced, with 28 per cent of law professors now female. ${ }^{17}$ These statistics capture only part of the experience of women in teaching law.

Turning to Māori academics, as at October 2017 and in accordance with my once again rudimentary collation of statistics from the law school websites, 6 per cent (or in numbers of persons, 10 Māori) teach law at five of the six law schools (on this count, Canterbury falls short with no Māori law lecturers, but others like Otago with consistently only one Māori academic is little better). It is interesting to reflect that when I began teaching law in 1999, there were 10 of us spread across the law schools - so even though some of the persons have changed, the numbers have not, even over nearly 20 years. ${ }^{18}$ This is a critical and significant issue for the teaching of law (including for the profession of law) and becomes the primary point of my address here this evening: knowing our first laws - tikanga Māori - must become a foundational part of the law degree and valuing of Māori in the teaching of law is an important component of this. Our country's faculties of law at the very least need to be keeping pace with Māori students in the study of law. In 2016, 10 per cent of all LLB and LLB Honours completions across the country were Māori students. ${ }^{19}$

14 Angharad O'Flynn "New Zealand Women's Law Journal Te Aho Kawe Kaupapa Ture a ngā Wāhine" (2017) 913 LawTalk 71. Women made up 18 per cent of practising QCs on 1 February 2017: Geoff Adlam "Spotlight on Barristers" (15 May 2017) New Zealand Law Society <www.lawsociety.org.nz>.

15 New Zealand Law Society "By the Numbers" (11 April 2014) <www.lawsociety.org.nz>.

16 While there are an equal number of male and female lawyers employed in law firms, only 27 per cent of law firm partners are female: Adlam, above n 13.

17 The total number of professors counted were 57 (41 male and 16 female).

18 For a brief account of Māori who were lecturing law in 1999 see Jacinta Ruru "Whānau versus whakapapa in the Māori Land Court: A Tribute to Nin Tomas" (2017) 5 Te Tai Haruru Journal of Māori and Indigenous Issues 121.

19 Murray, above n 13. 


\section{THE INDIGENOUS EXPERIENCE OF LAW SCHOOL}

Even though the legal profession is renowned for being a hard place for women and Māori here in Aotearoa New Zealand, the study of law has been, and in many respects remains, a hostile place for Indigenous peoples the world over ${ }^{20}$ While the law treated married women as having no property rights, ${ }^{21}$ the law treated Indigenous peoples as savages. ${ }^{22}$ Law was, and is, the most effective colonial tool to deprive Māori of our lands, knowledge, societal ways of being and our own law. ${ }^{23}$ Moreover, legal education in this country has mostly always been entirely silent (if not dangerously disparaging) on things that matter dearly to Māori:

- When Sir Āpirana Ngata studied law, the Treaty was regarded as "a simple nullity". ${ }^{24}$

- In John Chadwick's time of early practice, change was commencing with, for example, the creation of the Waitangi Tribunal. ${ }^{25}$

- In the time of our students today, there is more respect for the Treaty in the legal profession, but still little holistic reflection in our law schools about our first laws: Māori laws.

While Māori have certainly pushed the boundaries of the colonial state law since its inception in these lands in the 1840s, Māori influence from within the canons of law is relatively new. Sir Āpirana

20 See Patricia A Monture "Now that the Door is Open: First Nations and the Law School Experience" (1990) 15 QLJ 179; John Borrows "Fourword: Issues, Individuals, Institutions and Ideas" (2002) 1 ILJ vii; Stephanie Milroy "Waikato Law School: An Experiment in Bicultural Legal Education - Part 1: Biculturalism and the Founding of Waikato Law School" (2005) 8(2) Yearbook of New Zealand Jurisprudence 173; Leah Whiu "Waikato Law School: An Experiment in Bicultural Legal Education - Part 2: The Reality of Being Māori at Waikato Law School" (2005) 8(2) Yearbook of New Zealand Jurisprudence 196; Gemma McKinnon "Supporting the Next Generation of Indigenous Law Students" (2014) 8 Indigenous Law Bulletin 3; and Jacinta Ruru "Toitū te Whenua, Toitū te Mana" (2016) 14 Otago LR 243. Dr Karyn Paringatai, Associate Professor Suzanne Pitama and I as co-directors of the newly established University of Otago Poutama Ara Rau Research Theme 2016-2020 are seeking multidisciplinary researched solutions to better enable Māori knowledge and practices in tertiary teaching: see University of Otago "Te Poutama Māori" <www.otago.ac.nz>.

21 William Blackstone Commentaries on the Laws of England vol 1 (London, 1809) at 441; Bettina Bradbury "From Civil Death to Separate Property: Changes in the Legal Rights of Married Women in NineteenthCentury New Zealand" (1995) 29 New Zealand Journal of History 40; Briggs, above n 6; and Nicola Peart "Property Rights on Death: Policies in Conflict" (2017) 15 Otago LR 25.

22 Wi Parata v Bishop of Wellington (1877) 3 NZ Jur (NS) 72 (SC). This case was not overruled until the Ngati Apa case in 2003 (Attorney-General v Ngati Apa [2003] 3 NZLR 643 (CA)).

23 For an introduction to the colonialism of law see for example Ani Mikaere Colonising Myths: Māori Realities. He Rukuruku Whakaaro (Huia Publishers, Wellington, 2011).

24 Wi Parata, above n 22, at [78].

25 See Treaty of Waitangi Act 1975. 
Ngata began this and many are still continuing the journey. Ngata's vision is encapsulated in this wellknown proverb: 26

'E tipu e rea, Ko tō ringa ki nga rākau a te pākehā, Hei ora mō te tinana, Ko tō ngākau ki ngā tāonga a ō tipuna Māori, Hei tikitiki mō tō māhuna': 'Grow and branch forth tender youth, Take on and use the tools of the pakeha, For the sustenance of your wellbeing, Your heart to the treasures of your ancestors, To wear as an adornment/plume for your head'.

We now need a new collective spirit to hold dear to as we further reconcile with Māori. As part of this journey, we must consider the place of our first laws - tikanga Māori - as law and as part of our complete legal system today.

\section{A FRAMEWORK FOR RECOGNISING TIKANGA MÄORI}

If settler legal systems wish to realise aspirations for true reconciliation - restitution - with Indigenous peoples, then an important component of this is to recognise Indigenous peoples' laws. One way to advance this is to consider fully the first laws of Aotearoa New Zealand. Justice Joe Williams, in particular, has provided a powerful framework for us to do just this. ${ }^{27}$ Drawing on Justice Williams' work, this framework highlights that our law consists of three components: Kupe's law, Cook's law and Aotearoa New Zealand law.

\section{A Kupe's Law}

The lands of Aotearoa were and are Māori lands. These lands hold stories, traditions and laws that regulate human behaviour. These laws have sources and practices in: ${ }^{28}$

(a) whanaungatanga (extended family, relationships and responsibilities; whakapapa (genealogy); the glue holding the Māori world together; and centrality of kinship);

(b) mana (authority, control, influence, prestige and power leading to leadership);

(c) tapu (sacred, respect (complementary opposite: noa) and different roles, for example, social (keeping safe), political (leadership, ceremony) and spiritual (wairua/life force));

26 Māori Television "120 Years Since Admission of Tā Apirana Ngata" (23 March 2017) <www.maoritelevision.com>. For further information about Sir Āpirana Ngata, see McLintock, above n 7.

27 Joe Williams "Lex Aotearoa: An Heroic Attempt to Map the Māori Dimension in Modern New Zealand Law" (2013) 4 Wai L Rev 1.

28 Williams, above n 27. See also ET Durie "Will the Settlers Settle? Cultural Conciliation and Law" (1996) 8 Otago LR 449; Richard Benton, Alex Frame and Paul Meredith Te Mātāpunenga: A Compendium of References to the Concepts and Institutions of Māori Customary Law (Victoria University Press, Wellington, 2013); Hirini Moko Mead Tikanga Māori: Living by Māori Values (rev ed, Huia Publishers, Wellington, 2016); Carwyn Jones New Treaty New Tradition: Reconciling New Zealand and Māori Law (Victoria University Press, Wellington, 2016); and many of the Waitangi Tribunal reports including Waitangi Tribunal He Kura Whenua Ka Rokohanga - Report on Claims about Reform of Te Ture Whenua Māori Act 1993 (Wai 2478, 2016). 
(d) utu (reciprocity and obligation); and

(e) kaitiakitanga (stewardship, guardianship and care for one's own).

\section{B Cook's Law}

With the arrival of the Europeans and the bringing with them of a long deep history of law from England, a natural collision occurred with the first laws of the country. At the frontline of this collision has been:

(a) the legal relevance of Te Tiriti o Waitangi (the Treaty of Waitangi); ${ }^{29}$

(b) the applicability of the common law doctrine of native title; ${ }^{30}$ and

(c) the creation of Māori freehold land. ${ }^{31}$

\section{Aotearoa New Zealand's Law}

As Māori began to increase in numbers within the legal profession and society started to change its views about the Treaty of Waitangi, noticeable change in the 1980s commenced. Many hearing this address this evening have been influential in this movement.

Every day now, the courts are dealing with all sorts of interesting issues of evidence of our nation's first laws. Legislation is requiring this to occur. The Resource Management Act 1991 recognises the practices of kaitiakitanga (guardianship) and the importance of wāhi tapu (sacred sites) and taonga (treasures) in lands and waters. ${ }^{32}$ The Property (Relationships) Act 1976 recognises that taonga (treasures) ought not to be considered family chattels in relationship property divisions. ${ }^{33}$ Te Ture Whenua Māori Act (Māori Land Act) 1993 accepts that a child can be adopted in accordance with Māori customary laws and values (known as whāngai) and succeed to land interests. ${ }^{34}$

Significantly, the Supreme Court, in 2012, had to consider which law had dominance to determine where a deceased Māori male could be buried: Māori law (tikanga Māori) or the common law. ${ }^{35}$ While the common law trumped in this specific case, the Supreme Court accepted that tikanga is part

29 See Wi Parata, above n 22; and Te Heuheu Tukino v Aotea District Māori Land Board [1941] NZLR 590, [1941] AC 308 (PC).

30 See Wi Parata, above n 22; and Robert J Miller and others Discovering Indigenous Lands: The Doctrine of Discovery in the English Colonies (Oxford University Press, Oxford, 2010).

31 See Native Lands Act 1862; Native Lands Act 1865; and Richard Boast The Native Land Court 1862-1887: A Historical Study, Cases and Commentary (Thomson Reuters, Wellington, 2013).

32 See Resource Management Act 1991, ss 7 and 6(e) respectively.

33 See s 2.

34 See s 108.

35 Takamore v Clarke [2012] NZSC 116, [2013] 2 NZLR 733; and Natalie Coates "The Recognition of Tikanga in the Common Law of New Zealand" [2015] NZ L Rev 1. 
of New Zealand's common law, for example: "Claims based on whakapapa [genealogy] and tikanga observed by the hapū [subtribe] of the deceased are entitled to great weight in New Zealand law and may well prevail in a particular case" 13 and "Māori custom according to tikanga is therefore part of the values of the New Zealand common law". ${ }^{37}$

Our government today - all three branches - cannot escape the evidence of our first laws that is, Kupe's law or tikanga Māori. But the profession of teaching law has barely caught up to this fact. The change in the practice of law will perhaps eventually demand our graduates to be better equipped to know and understand our country's first laws. At the forefront of this inclusion must be the visions and aspirations of our Māori communities, iwi, whānau and hapū. And perhaps it is their voices now encapsulated in our Treaty settlements that will provide the most extraordinary changes to our legal system.

The 20th anniversary of the signing of the Deed of Settlement that led to the Ngāi Tahu Claims Settlement Act 1998 is now being celebrated. Embedded within this statute are purakau (stories or traditions) of the land. For example, sch 14 provides a glimpse into the story of who Aoraki (Mount Cook) is and how Aoraki, as the son of Raki (the Sky Father), came to be the tallest mountain. Aoraki and his brothers were travelling on their boat trying to find Earth Mother when: ${ }^{38}$

The waka listed and settled with the west side much higher out of the water than the east. Thus the whole waka formed the South Island, hence the name: Te Waka o Aoraki. Aoraki and his brothers clambered on to the high side and were turned to stone. They are still there today. Aoraki is the mountain known to

Pākehā as Mount Cook, and his brothers are the next highest peaks near him.

These purakau can be the catalyst to transform our legal education and more broadly society's understandings of law. And so, I turn to our nation's recent reconciliation settlements that have utilised the tool of legal personality to share why I believe these negotiated agreements give us the best hope to change legal education and, more broadly, law as we know it, today in this country.

\section{A MARRIAGE OF LAWS: LEGAL PERSONALITY OF INDIGENOUS ANCESTORS}

In July 2014, Te Urewera, a large forest in the North Island, was transformed from a national park into a legal person with "rights, powers, duties, and liabilities". ${ }^{39}$ New Zealand law did the same again three years later. In March 2017, our third longest river, the Whanganui River, became a legal

\footnotetext{
36 Takamore v Clarke, above n 35, at [9].

37 At [94].

38 Ngāi Tahu Claims Settlement Act 1998, sch 14.

39 Te Urewera Act 2014, s 11.
} 
person. ${ }^{40}$ Of course these places always have had personality as ancestors in the world of the Indigenous Māori peoples. Our state legal system has now recognised this too. Most of my life, my family and Māori families across the country have dreamed of, and fought hard for, society to better recognise Māori relationships with lands and waters. My research has been devoted to arguing why colonial countries such as New Zealand need to look for new ways to meaningfully reconcile with Indigenous peoples to displace legal assumptions of Crown ownership and governance of lands and waters. ${ }^{41}$ The concept of utilising legal personality is an amazing way to do just this. ${ }^{42}$ The possibilities for recognising Indigenous legal personality of the environment can seismically shift the very foundations of our legal systems to address centuries of legal and societal racism and bias. Here in New Zealand, legal personality:

(a) honours the vision of our ancestors who signed Te Tiriti o Waitangi (the Treaty of Waitangi) in 1840 that laid the blueprint for how two peoples - the British and Māori - could respectfully live together in our land of the long white cloud; ${ }^{43}$

(b) transforms our nation's legal system by placing at the forefront a Māori understanding of the world and our responsibilities as human beings; and

(c) disrupts notions of sovereignty offering, as one of our past Ministers of Māori Affairs, Hon Pita Sharples, has said, a "profound alternative to the human presumption of sovereignty over the natural world". ${ }^{4}$

It is remarkable that our country has been able to recognise a large forest and a long river as having legal personality as Indigenous ancestors. This is something I never thought would happen, despite arguing it was possible.

I grew up encased deep in the beauty of the South Island, far away from my Dad's childhood stomping ground of our tribal lands of Raukawa where he grew up next door to the humble family

40 Te Awa Tupua (Whanganui River Claims Settlement) Act 2017, s 14.

41 See for example my Inauguaral Professorial Lecture that provides an overview of my scholarship: Jacinta Ruru "Toitū te Whenua, Toitū te Mana" (2016) 14 Otago LR 243.

42 As initially strongly argued in James DK Morris and Jacinta Ruru "Giving Voice to Rivers: Legal Personality as a Vehicle for Recognising Indigenous Peoples' Relationships to Water?" (2010) 14(2) AILR 49.

43 Aotearoa, one of the Māori names for New Zealand, means "land of the long white cloud".

44 (23 July 2014) 700 NZPD 19463. See also my discussion of legal personality from an Indigenous perspective in Jacinta Ruru "A Treaty in Another Context: Creating Reimagined Treaty Relationships in Aotearoa New Zealand" in John Borrows and Michael Coyle (eds) The Right Relationship: Reimagining the Implementation of Historical Treaties (University of Toronto Press, Toronto, 2017) 305; Jacinta Ruru "Reimagining Governance for 'Yellowstone' Modelled National Parks in the New Era of Indigenous Legal Recognition" in Lars Elenius, Christina Allard and Camilla Sandström (eds) Indigenous Rights in Modern Landscapes: Nordic Conservation Regimes in Global Context (Routledge, Oxon, 2017) 113; Jacinta Ruru "Tūhoe-Crown Settlement - Te Urewera Act 2014" (2014) October Māori LR 16; and Jacinta Ruru "Legal Personality of the Environment, part I" (podcast, 30 Nov 2017) McGill Law Journal <http://lawjournal.mcgill.ca〉. 
Paparamu Marae bookended by my grandmother's nations of Ngāti Ranginui and Ngāti Maniapoto. And we were far away too from my Pākehā mother's home upbringing in her loved city, New Plymouth.

My childhood home was in the tribal lands of Ngāi Tahu: at the head of Lake Wakatipu, Glenorchy; at the foot of the majestic mountain peaks of Mount Earnslaw; beside the braided waters of the Dart River; surrounded by lands preserved in the renown Fiordland and Mount Aspiring national parks managed by the Department of Conservation (a government department charged with managing one third of Aotearoa New Zealand's land that is protected for the public for conservation purposes).${ }^{45}$ My home was a place of overlaid English names and English histories of first discovery of places. In school we only learnt how Nathanael Chalmers was the first European to sight Lake Wakatipu and how William Gilbert Rees was the first European to settle in the area.

Something seemed terribly amiss and remiss. Was I not also living at the head of a sleeping giant, on the boat that Maui, the demigod, used to catch the big fish that the Europeans named the North Island $?^{46}$ Was I not living near to the trails of the most precious traded resource in the Māori economy - greenstone, a place deep with centuries of Māori history and knowledge?

This childhood unease led me on my adult journey of inquiry and eventually to dreaming for better, more respectful, law that acknowledges Indigenous peoples' histories, stories, rights, responsibilities and interests in remaining stewards of lands and waters essential to cultural identity and survival. The discipline of law took hold of me in the 1990s. It was a chance encounter. It was not always obvious I would go to university. Few we knew had. But I loved the university environment for learning and I particularly loved the puzzle of law. However, I struggled with much of the colonial curriculum. It was perplexing to learn about legal positivism, primary rules and secondary rules, clear cases and hard cases, all containing underlying messages that law is objective and just. I could not reconcile this standard of law with the stories my father's family told. These stories are about dispossession from ancestral land from the 1860s onwards, through insidious legislation that confiscated much of our lands and criminalised our knowledge systems. As just one example, colonial laws were enacted that made illegal the collection and use of much of the native flora and fauna ${ }^{47}$ and certainly outlawed Māori medicinal knowledges and practices dependent on plants. ${ }^{48}$ I knew our experiences were not unique; all Māori families have similar accounts. These experiences were mostly invisible in all of my schooling, including the law school curriculum. Studying law gave me an insight into how the law was used to achieve colonial goals; it did not

45 See Conservation Act 1987.

46 To read about the Lake Wakatipu being the sleeping giant see sch 75 of the Ngāi Tahu Claims Settlement Act

47 Native Plants Protection Act 1934.

48 Tohunga Suppression Act 1907. 
convince me that law operates on an unbiased, neutral terrain. So, I came to regard the subject of law as both shocking and fascinating. But the discipline of law was changing.

By the time I began teaching law in the late 1990s, we had a permanent commission of inquiry, the Waitangi Tribunal, to consider remedies for the government's long history of seriously breaching the principles of the Treaty of Waitangi. The Courts had come to regard the Treaty as "a living instrument", ${ }^{49}$ an "embryo", ${ }^{50}$ rather than as a "simple nullity". ${ }^{51}$ Māori were changing the legal landscape and our legal system was listening and responding. Fast forward, and today we have two national laws that recognise Indigenous ancestors as legal persons.

What is this legal personality? Well, as persons, you and I, we have rights and powers. In law, we are known as natural persons. In contrast, the law also recognises legal persons. Legal personality is not a novel concept in and of itself. For some time now, many countries have recognised the legal personhood of, for example, incorporated companies. Once, Lord Denning of England likened a company to the human body: "It has a brain and nerve centre which controls what it does. It also has hands which hold the tools". ${ }^{52}$ And so in New Zealand, like in many other countries, companies can have the rights, powers and privileges of a natural person. What is remarkable, with the recognition of a once national park and a still long river, is that here legal personality has extended to the environment.

In a Western context, back in 1972, American Professor Christopher Stone had a vision for environmental legal personhood. ${ }^{53}$ He wrote a book titled Should Trees Have Standing? and answered that question by telling us that trees, oceans, animals and the environment as a whole should be bestowed with legal rights and a legal voice so that they could be heard in courts. ${ }^{54}$ But Te Urewera and the Whanganui River did not become legal persons to simply protect them. The law was already providing layers of environmental protection against degradation. For example, Te Urewera had been a national park. This is the highest level of environmental protection possible in our legal system. The

49 New Zealand Māori Council v Attorney-General [1987] 1 NZLR 641 (CA) at 656.

50 At 663 .

51 At 715. See also Jacinta Ruru (ed) 'In Good Faith': Symposium Proceedings Marking the 20th Anniversary of the Lands Case (New Zealand Law Foundation, Wellington, 2008).

52 HL Bolton (Engineering) Co Ltd v TJ Graham \& Sons Ltd [1957] 1 QB 159 (CA) at 172. See further HAJ Ford and RP Austin Ford and Austin's Principles of Corporations Law (7th ed, Butterworths, Australia, 1995) at 34; Neil Campbell "Corporate Personality" in Peter Watts, Neil Campbell and Christopher Hare (eds) Company Law in New Zealand (2nd ed, LexisNexis, Wellington, 2016) 23 at 33; and Lee v Lee's Air Farming Ltd [1959] NZLR 393 (CA) at 398.

53 Christopher D Stone "Should Trees Have Standing? - Toward Legal Rights for Natural Objects" (1972) 45 S Cal L Rev 450.

54 Christopher D Stone Should Trees Have Standing? Law, Morality, and the Environment (3rd ed, Oxford University Press, New York, 2010). 
government department charged with managing the then Te Urewera National Park was legally required to preserve the lands in perpetuity in a natural state. ${ }^{55}$ The legal personhood of Te Urewera and the face of the Whanganui River are solutions borne from the heartache and struggle to survive the onslaught of European colonisation.

In the lands of Te Urewera and the waters of the Whanganui River, the colonial atrocities of warfare, destruction and land confiscation have seeped deep, leaving societies in disarray. The histories of the last 150 years or so are of our government killing non-combatant Māori men, women and children, using scorched-earth policies to destroy Māori homes and food supplies, stealing Māori land, wrongfully imprisoning Māori, criminalising Māori customs and medical knowledge, and beating children for speaking the Māori language. ${ }^{56}$ The wrongs of the past are the wrongs of the present too. Just in 2007, 300 armed police raided Māori in Te Urewera in response to alleged terrorism preparation camps. ${ }^{57}$ The horror of the day lead to no discovery of a military camp and eventually to only four persons being found guilty of some firearms charges. ${ }^{58}$

It is remarkable that our country has now been able to reach settlement for Crown breaches of the Treaty of Waitangi in an innovative, positive and inclusive manner that pushes the boundaries of our national imagination. ${ }^{59}$

The Te Urewera Act 2014 is perhaps one of the most beautifully written statutes. While I do not routinely encourage the reading of legislation for joy, this is one exception. It reads: ${ }^{60}$

\section{Te Urewera}

(1) Te Urewera is ancient and enduring, a fortress of nature, alive with history; its scenery is abundant with mystery, adventure, and remote beauty.

(2) Te Urewera is a place of spiritual value, with its own mana and mauri.

55 National Parks Act 1980, s 4. See also Conservation Act.

56 See for example Waitangi Tribunal Ko Aotearoa Tēnei: A Report into Claims Concerning New Zealand Law and Policy Affecting Mãori Culture and Identity (Wai 262, 2011); and Waitangi Tribunal Te Urewera: Combined Record of Inquiry for the Urewera District Inquiry (Wai 894, 2018).

57 See Danny Keenan (ed) Terror in Our Midst? Searching for Terrorism in Aotearoa New Zealand (Huia Publishers, Wellington, 2008); and "Operation 8" (documentary directed by Abi King-Jones and Errol Wright, 2011).

$58 \quad R v$ Signer [2012] NZHC 1423; Iti v R [2012] NZCA 492; and Signer $v$ R [2013] NZSC 40. See also "'Urewera Four' Pair Jailed" The Dominion Post (online ed, Wellington, 24 May 2012).

59 For a broader insight into the Treaty of Waitangi claims settlement with Tūhoe see Tūhoe Claims Settlement Act 2014; and Rawinia Higgins "Tūhoe-Crown Settlement - Te Wharehou o Tūhoe: The House that 'We' Built" (2014) October Māori LR 7.

60 Section 3. 
(3) Te Urewera has an identity in and of itself, inspiring people to commit to its care.

\section{Te Urewera and Tūhoe}

(4) For Tūhoe, Te Urewera is Te Manawa o te Ika a Māui; it is the heart of the great fish of Maui, its name being derived from Murakareke, the son of the ancestor Tūhoe.

(5) For Tūhoe, Te Urewera is their ewe whenua, their place of origin and return, their homeland.

(6) Te Urewera expresses and gives meaning to Tūhoe culture, language, customs, and identity. There Tūhoe hold mana by ahikāroa; they are tangata whenua and kaitiaki of Te Urewera.

\section{Te Urewera and all New Zealanders}

(7) Te Urewera is prized by other iwi and hapū who have acknowledged special associations with, and customary interests in, parts of Te Urewera.

(8) Te Urewera is also prized by all New Zealanders as a place of outstanding national value and intrinsic worth; it is treasured by all for the distinctive natural values of its vast and rugged primeval forest, and for the integrity of those values; for its indigenous ecological systems and biodiversity, its historical and cultural heritage, its scientific importance, and as a place for outdoor recreation and spiritual reflection.

Just as Te Urewera is the heart of the great fish of Maui (Maui being our demigod who fished up the North Island of New Zealand), the Whanganui River is an ancestor of the Whanganui tribe; it is a spiritual and physical entity. It is an indivisible and living whole from the mountains to the sea, incorporating all of its physical and metaphysical elements. ${ }^{61}$

Internationally, others too are seeking legal personhood of their rivers - Rivers Ganges and Yamuna in India and the Colorado River in the United States are some examples ${ }^{62}$ - but perhaps their motivation is simply for environmental protection. I think legal personality offers us around the world much more than this. It has the power to displace and disrupt Western bias in our society and in our state laws.

Here in Aotearoa New Zealand, legal personhood makes sense because it aligns with the Indigenous Māori worldview (and it neutralises the hotly contested issue of ownership of lands and

61 See Te Awa Tupua (Whanganui River Claims Settlement) Act, s 12.

62 Mohd Salim v State of Uttarakhand Writ Petition (PIL) No 126 of 2014; Michael Safi "Ganges and Yamuna Rivers Granted Same Legal Rights as Human Beings" The Guardian (online edition, London, 21 March 2017); Complaint for Declaratory Relief Colorado River Ecosystem v State of Colorado No 1:17-CV-0231625 (D Colo, 25 September 2017) 2017 WL 4284548; Motion to Dismiss Colorado River Ecosystem v State of Colorado No 17-CV-02316-NYW (D Colo, 17 October 2017) 2017 WL 4699840; and Lindsay Fendt "Colorado River 'Personhood' Case Pulled by Proponents" Aspen Journalism (online ed, Aspen Colorado, 5 December 2017). 
waters). In practice, Te Urewera ceased to be Crown land, and ceased to be a national park. ${ }^{63}$ It is now managed by a board of mostly Tūhoe persons where Māori concepts of law drive all decisionmaking, where rules manage the people rather than the land. ${ }^{64}$ It is certainly a management plan like no other. The plan's opening words include: "Deliberatively, we are resetting our human relationship and behaviour towards nature. Our disconnection from Te Urewera has changed our humanness. We wish for its return."65

For the ancestral river, the Whanganui River, a human face is being established to speak for and on behalf of the river, and to promote and protect the health and well-being of the river. And yes, Te Urewera and the Whanganui River, as legal persons, can be sued. ${ }^{66}$

\section{CONCLUSION}

I trained as a lawyer in the 1990s and have been teaching and researching law for nearly 20 years. I, and many others, have consistently urged legislative reform of our government's assumptions of owning and managing lands and waters, including national parks and rivers. While I dreamed for radical legislative reform, we are now at this significant juncture. The Te Urewera Act 2014 and the Te Awa Tupua (Whanganui River Claims Settlement) Act 2017 make me immensely proud to be a New Zealander. A Māori way of understanding, caring for and nourishing land and water is now prescribed legal force. The national story of discovery and naming our lands has been seriously disrupted. There is more to these places than a European Western perspective and the tool of legal personality as used in New Zealand shows us this.

And so, in conclusion, returning to Justice Williams' framework, is this how we could come to view and teach law in this country? And if we are to become serious about recognising our first laws - Kupe's law and tikanga Māori - what role does the legal profession, including the law lecture rooms, have in teaching these laws?

Indigenous law academics are closely considering these issues. In particular, the world renown Anishinabe/Ojibway law professor John Borrows has written extensively about the power and

63 See Te Urewera Act 2014, s 12.

64 See "Te Kawa o Te Urewera" (2017) Tūhoe <www.ngaituhoe.iwi.nz>.

65 At 8 (emphasis omitted).

66 Te Urewera Act, s 11; and Te Awa Tupua (Whanganui River Claims Settlement) Act, s 14. 
relevance of Indigenous laws. ${ }^{67}$ The questions he poses for the Canadian legal system are questions we too need to consider. Some of these questions include: ${ }^{68}$

(a) Should the teaching of Indigenous law remain primarily within Indigenous communities?

(b) Should the teaching of Indigenous laws occur in law schools?

(c) Is it possible to categorise Indigenous law?

(d) Should Indigenous law be taught in English?

(e) Can Indigenous law be organised by one theory or approach?

(f) Can Indigenous law be organised by common law categories?

I hope that, with all of the incredible momentum that is taking place in the profession of law, and most obviously in the necessary engagement to know and understand contemporary tikanga Māori, we have an enormous opportunity to embrace Māori visions of what is right and what is just.

Tonight is about honouring those who have made a difference in our legal system. All of us have stories and experiences of change and influence. Returning to the University of Otago, the faculty of law I know best, we are incredibly proud of all of our Māori alumni including:

(a) one of our first Otago Māori graduates of law the now Chief Judge Wilson Isaac of the Māori Land Court and Chairperson of the Waitangi Tribunal; ${ }^{69}$

(b) Warren Alcock and Associate Professor Claire Charters, our first two Māori to graduate with LLB Honours at Otago:

(ii) Warren, a sports lawyer, named by our local Otago Daily Times newspaper as Agent Alcock in a wonderful profile story this year recognising him as one of the most influential figures in New Zealand rugby, in 2015 named 24th in the New Zealand Lawyer Power List; ${ }^{70}$

(iii) Claire who has gone on to have a stellar academic career with postgraduate law degrees from New York University and University of Cambridge and who was named a Rutherford Fellow in 2017, an extraordinary achievement; and

(c) Kristen Maynard, who established the Māori law student body at Otago in 1993 named Te Roopu Whai Putake.

67 See for example John Borrows Recovering Canada: The Resurgence of Indigenous Law (University of Toronto Press, Toronto, 2002); John Borrows Canada's Indigenous Constitution (University of Toronto Press, Toronto, 2010); and John Borrows Drawing Out Law: A Spirit's Guide (University of Toronto Press, Toronto, 2010).

68 John Borrows "Heroes. Tricksters, Monsters, and Caretakers: Indigenous Law and Legal Education" (2016) 61 Mcgill LJ 795. See also Sonia Lawrence and Signa Daum Shanks "Indigenous Lawyers in Canada: Indentity, Professionalization, Law" (2015) 38 Dal LJ 503.

69 See Pita Sharples "New Chairperson for the Waitangi Tribunal" (press release, 14 September 2009).

70 See Sally Rae "Agent Alcock" Otago Daily Times (online ed, Dunedin, 27 March 2017). 
The photos below capture some of these achievements in our 21 st birthday celebrations for $\mathrm{Te}$ Roopu Whai Putake.

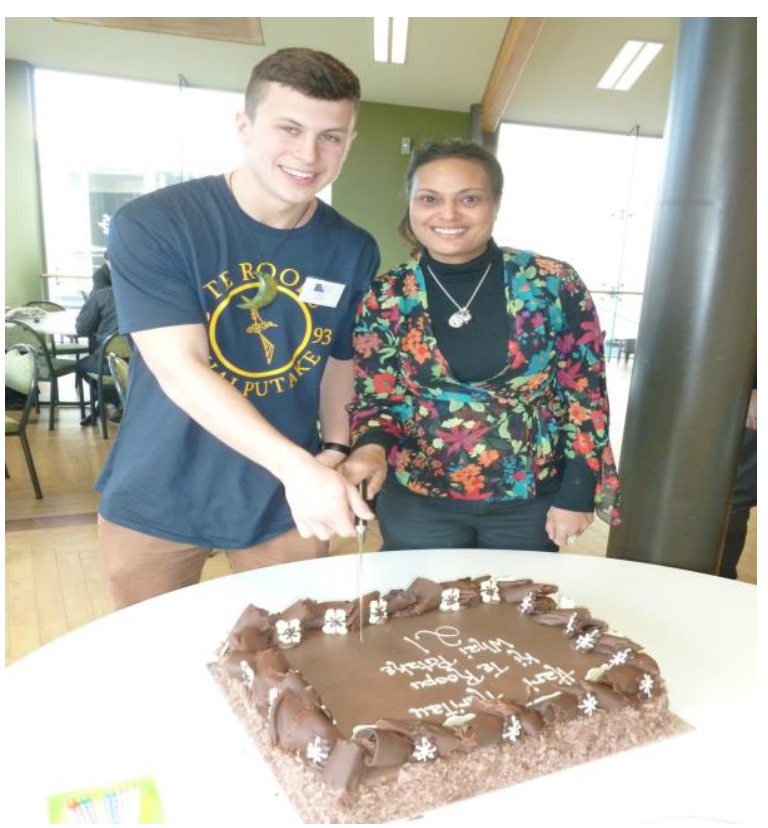

Photo: Adam Tapsell and Kristen Maynard, University of Otago, 2014. Source: Jacinta Ruru.

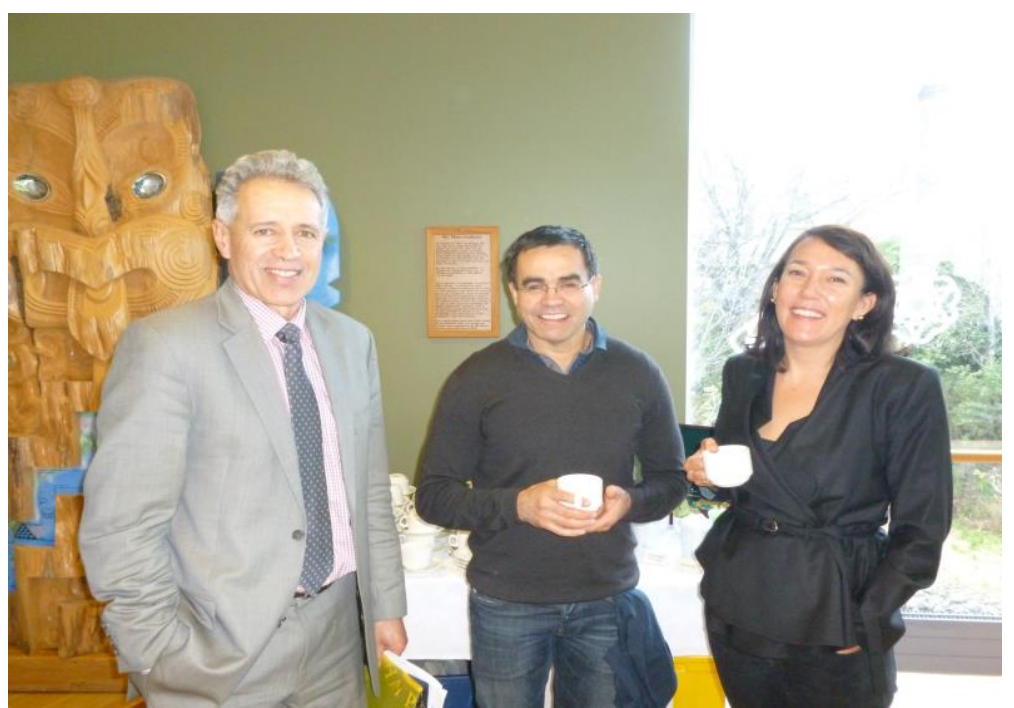

Photo: Chief Judge Wilson Isaac, Warren Alcock and Associate Professor Claire Charters, University of Otago, 2014. Source: Jacinta Ruru. 
While few in numbers, the Māori achievement in law is prominent. I sincerely hope that together as a legal profession we can do more to embrace the Māori influence of law from within the law. It is the pioneering spirit that we must continue to hold dear, just as we continue to consider not only the role of women, but also Māori, in the legal profession. Knowing our first laws - tikanga Māori should soon become a foundational part of the law degree, sitting alongside compulsory law subjects such as torts, criminal law, property law and public law.

We come from the land and waters. Lands and waters have their own heartbeat, health and soul. Land, water: one. Mauri Ora. Ngā mihi. 